International Journal of Life Sciences
Available online at http://sciencescholar.us/journal/index.php/ijls
Vol.3 No. 1, April 2019, pages: 71 78
e-ISSN: 2550-6986, p-ISSN: 2550-6994
https://doi.org/10.29332/ijls.v3n1.274

\title{
Recovery of Ancestral Knowledge for Production of Traditional Manabí Cocoa Paste
}

\author{
Q Crossiark \\ Telly Yarita Macias Zambrano a, Ingri Catherine Garcia Castro b, Carmen Liliana Mera Plaza c, \\ Ricardo Munoz Farfan d
}

Article history: Received ..., Accepted: ..., Published: ...

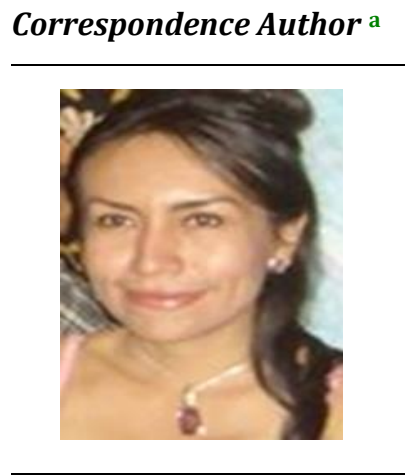

\section{Keywords}

ancestral, benefits, chocolate, conservation, elaboration

\begin{abstract}
The high family consumption of chocolates and cocoa powders with a high content of sugars and saturated fats, and on the contrary a very low content of cocoa paste is a problem. The objective was to recover the ancestral knowledge in the elaboration and conservation of the traditional Manabi cocoa paste. The experimental method was used for the elaboration and conservation of cocoa paste in clay pots with dried guineo leaves, in glass jars, at room temperature, and in refrigeration. Through the technique of interviewing 10 peasant women from the rural area of Chone, the way of elaboration and conservation of the cocoa ball was known. The main results: increase of the useful life of the cocoa ball wrapped in dried guinean leaves and stored in clay pots at room temperature, due to the decrease in humidity up to 180 days. As conclusions: little use of ancestral knowledge in the elaboration and conservation of traditional Manabí cocoa paste, unlike the consumption of refined chocolates with low cocoa content.
\end{abstract}

e-ISSN: 2550-6986, p-ISSN: 2550-6994@ Copyright 2019. The Author. SS Journals Published by Universidad Técnica de Manabí. This is an open-access article under the CC BY-SA 4.0 license (https://creativecommons.org/licenses/by-sa/4.0/) All rights reserved.

\section{Contents}

Abstract 71

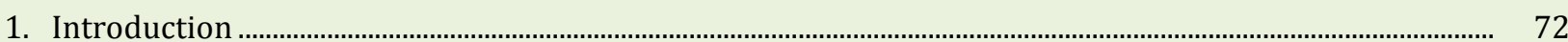

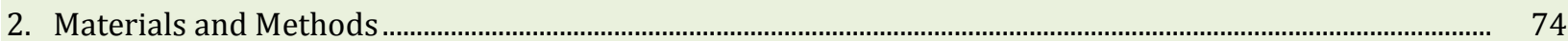

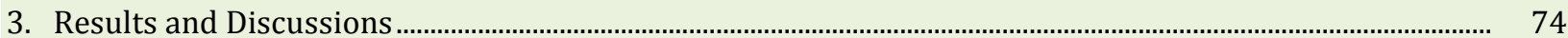

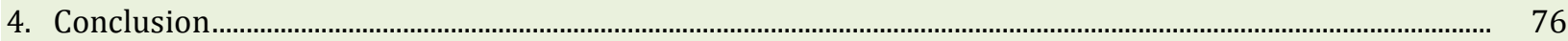

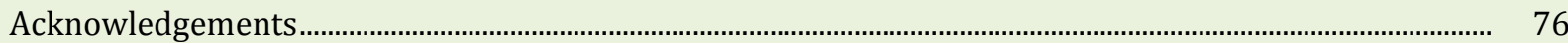

a Master in Agricultural Engineering, Professor at the Higher Technological Institute Paulo Emilio Macias, Portoviejo, Manabí, Ecuador

b Student of the fourth semester of the career of Superior Technology in Agriculture at the Higher Technological Institute Paulo Emilio Macias, Portoviejo, Manabí, Ecuador

c Bachelor of Accounting and Auditing, Higher Technological Institute Paulo Emilio Macias, Portoviejo, Manabí, Ecuador

d Mechanical Engineer, Higher Technological Institute Paulo Emilio Macias, Portoviejo, Manabí, Ecuador 


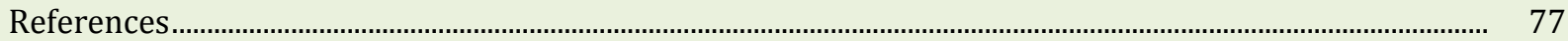

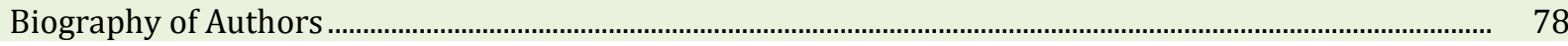

\section{Introduction}

Some terminologies used are: comal that refers to a paila made of mud, the sliding that is a dryer made of wood and provided with large drawers that open for all four sides in addition to the roof, used to dry cocoa; the tendal that is a space covered with chopped cane on which the cocoa is spread to dry it; kills that refers to a plant or small tree; Cocoa ball is the roasted, ground, kneaded grain and given the semi-milled form for consumption as a hot liquid drink. Pedrero (2011), emphasizes that current research must recognize and highlight ancestral knowledge, as in the case of the production of artisanal chocolate, where producers conserve ancestral knowledge; this allows obtaining healthy, natural and flavored foods that differentiate it. The traditional knowledge called ancestral knowledge is the knowledge accumulated by popular cultures and transmitted from generation to generation orally (Lizcano et al., 2014).

In the case of food, they are considered traditional when they conserve cultural patterns such as production processes and forms of consumption, such knowledge has been transmitted from generation to generation, including the incorporation of new products that generate more varied foods (McClung, 2014) cited by (Córdova et al., 2018). In the traditional processes to elaborate food, implicit local knowledge that is part of their natural and cultural heritage is implied, so that these are created, developed, and transmitted to the community.

A beautiful legend tells that Quetzalcoatl, the god of the moon and the winds, discovered the cacao tree in the luminous fields of the children of the sun. He gave it to the men who called him. The Food of the Gods, cocoa had great value for the Maya and was used as currency, an element of commercial exchange and key piece in the preparation of food and drinks. Due to their physical characteristics, cocoa seeds became a pseudocurrency for commercial exchanges. According to the chronicles was Hernán Cortez, of the first to taste its flavor. Quetzalcóalt before leaving for Tapallan, he prophesied that he would return "where the sun rises". In the year designated in the Aztec calendar as "Ce-acalt" (1519 of the Christian era), just when the first Spaniards landed on the coasts of Mexico. This coincidence meant for the Aztecs the announced return of their exiled God. And the reception of the Spaniards as divine beings. Moctezuma offered visitors the most sacred drink for the Aztecs: the chocolate, made up of a mixture of cocoa, ground corn, pepper, various spices and natural aphrodisiacs; the result was a tonifying, energetic and aphrodisiac drink (Estrada, 2011).

For many years Ecuador is recognized as the largest producer of fine cocoa with an exquisite aroma and flavor. The first chocolate known in Ecuador is what is called "the chocolate ball" made by housewives. They grated the chocolate ball in hot water or milk. The traditional cocoa paste manabita is a drink with an incomparable flavor as well as its aroma, its elaboration is purely natural using a quality grain, drying, grinding and kneading in order to obtain the cocoa ball that is molded by the hands of the housewife, the result of this is an ancestral chocolate, natural and healthy (Macias, 2018).

The research problem focuses on the high family consumption of chocolates and cocoa powders with a high content of sugars and saturated fats, and on the contrary, very low content of cocoa paste. Chocolate powder is part of the basic basket of most families that have children of school age; chocolate milk in several presentations have a high demand because they are consumed by infants as refreshments daily, these products contain flavorings, preservatives, milk and a low content of cocoa. The main objective of the study is the recovery of ancestral knowledge in the elaboration and conservation of traditional Manabí cocoa paste.

For (Perea et al., 2009) the consumption of foods with a high content of antioxidants such as polyphenols is increasingly important for its health benefits. In this study, it was found that bitter chocolate has a polyphenol content comparable to that of green tea and superior to that of apple, which positions it as a functional food. The other products analyzed: chocolate with sugar, chocolate with cloves and cinnamon, and cocoa substitute, despite having a lower polyphenol content, present higher values than those reported for fruits.

The antioxidant activity is significant for cocoa products and it was found that the greatest antioxidant activity is bitter chocolate or pure cocoa liquor, while table chocolate with sugar and chocolate cloves and cinnamon presented an antioxidant activity 2.5 times lower because these products contain approximately $30 \%$ cocoa liquor. The chocolate substitute was the product with less antioxidant activity because this 
derivative is made with cocoa and vegetable fat. In all cases the antioxidant activity was lower than that of the reference substances gallic acid and ascorbic acid that showed very high values, however, it is important to bear in mind that these compounds are synthetic while the antioxidants contained in the cocoa are of origin natural

According to the study of Egas (2015), cocoa liquor is considered a product of high nutritional value because it is an important source of minerals as well as energy because of its high content of fat and carbohydrates. The nutritional composition of the cocoa liquor provides $500 \mathrm{kcal} / 100 \mathrm{~g}$ of energy, $11 \mathrm{~g} /$ $100 \mathrm{~g}$ of protein, $28 \mathrm{~g} / 100 \mathrm{~g}$ of carbohydrates, $55 \mathrm{~g} / 100 \mathrm{~g}$ of natural fat, $40 \mathrm{mg} / 44 \mathrm{~g}$ of calcium, $138.2 \mathrm{mg} / 44 \mathrm{~g}$ of magnesium; $5.9 \mathrm{mg} / 44 \mathrm{~g}$ of iron; $1.1 \mathrm{mg} / 44 \mathrm{~g}$ of copper; $190.5 \mathrm{mg} / 44 \mathrm{~g}$ phosphorus; $450.6 \mathrm{mg} / 44 \mathrm{~g}$ of potassium; $1.3 \mathrm{mg} / 44 \mathrm{~g}$ of sodium and $1.9 \mathrm{mg} / 44 \mathrm{~g}$ of zinc.

According to the publication of Iñamagua (2016), for a mother who is pregnant and weak due to malnutrition, the midwives liquefied the chocolate with chonta, milk, a glass of consecrated wine, panela and at the end they added an egg. The women had to drink the hot drink to improve their calories and energy by the vegetable protein, "this avoided the risks of abortion". Another way to use chocolate is in plasters or poultices; For pregnant women at risk of miscarriage due to colds or for those who have bleeding problems due to irregular menstrual periods, chocolate is mixed with zhima corn flour and hot is adhered to the belly "so that it is nourished by the pores so that takes out the cold; chocolate is used even as infusions for the nerves.

In the research of Campoverde \& Moreno (2013), organic cocoa beans have shown remarkable health benefits, in addition to not contain insecticides, pesticides or another chemical compound, in their composition contain magnesium, chromium, iron, vitamin C, omega 6 and fiber. Cocoa is very rich in flavonoids that are chemical compounds present in vegetables, which protect the body from oxidation that causes cellular deterioration and, therefore, aging. The flavonoids present in cocoa beans protect the nerve cells of the brain, restricting the dangers of coronary heart disease, preventing inflammation and damage at the cellular level. Organic cocoa beans are also composed of phenylethylamine, anandamide and theobromine, substances responsible for happiness and increased energy. Within the body act as neurotransmitters, which are chemical substances that work as antidepressants, inducing happiness.

According to the thesis of Chávez et al., (2008), they are rich in fats and carbohydrates, nutrients that provide energy to the body. Fats come from cocoa butter, which contains a large proportion of stearic acid, a saturated fatty acid that, unlike other fatty acids, does not increase the level of cholesterol in the blood. They are also a source of minerals such as potassium, phosphorus, magnesium, calcium, and vitamins. If the chocolate is with milk, or the cocoa dissolves in the milk, the contribution of calcium increases remarkably. Cocoa as a raw material contains vitamins such as thiamin (B1) and folic acid. Other beneficial components of cocoa are the photochemical elements (not nutritious), among which stand out: theobromine, which even being of the same family as caffeine has a much lower stimulating power and polyphenols (antioxidants), compounds that contribute to avoiding the oxidation of the so-called bad cholesterol (LDL-c) and that have been related to the prevention of cardiovascular disorders and to the stimulation of the body's defenses.

The best way to preserve chocolate is to keep it in a cool, dry place and away from very strong odors. The most important thing is that chocolate does not suffer sudden changes in temperature. The ideal temperature is between 15 and $18^{\circ} \mathrm{C}$. This temperature is difficult to find at room temperature, which is usually higher, and in the refrigerator, where it is lower. However, although it is not recommended, you can keep the chocolate in the fridge if necessary. If the chocolate is at a low temperature, it may lose aromas, and if it is at a high temperature, its texture and appearance may vary. In terms of humidity, it should be around $60 \%$. In the refrigerator, this humidity is greater, which affects the gloss and finish of the chocolate, appearing a layer or white spots known as fat-bloom. Also, be careful not to store chocolate near strong odors. These odors can be absorbed by the chocolate and alter its flavor. To store the chocolate in the fridge, you should protect it very well, wrapping it in a paper that absorbs moisture and then in an airtight plastic bag. Before consuming it, it must be removed with enough time to temper it and preserve its properties. There are more factors that influence this game of times, such as preservatives. The more industrial chocolate is, the more preservatives it contains and consequently, its duration will be longer. The same happens with sugar. The more sugar the chocolate contains, the longer it will last (Kuna, 2017).

Zambrano, T. Y. M., Castro, I. C. G., Plaza, C. L. M., \& Farfan, R. M. (2019). Recovery of ancestral knowledge for production of traditional Manabí cocoa paste. International Journal of Life Sciences, 3(1), $71-78$. https://doi.org/10.29332/ijls.v3n1.274 


\section{Materials and Methods}

Different materials were used to prepare the material, shown in table 1.

Table1

Amount needed for the elaboration cocoa paste

\begin{tabular}{|c|c|c|c|}
\hline \multicolumn{4}{|c|}{ Material } \\
\hline Quantity & Unit & Material & Origin \\
\hline 2 & $\begin{array}{c}\text { 6lb } \\
\text { egg } \\
\text { whites }\end{array}$ & $\begin{array}{l}\text { Cocoa beans creole dry } \\
\text { eggs }\end{array}$ & $\begin{array}{l}\text { Cacao } \\
\text { Creole chickens }\end{array}$ \\
\hline 50 & $\mathrm{Gr}$ & sweet spices & \\
\hline 1 & & Handmill & \\
\hline 1 & & Comal mud & \\
\hline 1 & & Cuchareta wood & \\
\hline 1 & & Firewood stove & timber Trees \\
\hline 1 & & Firewood & dry branches of timber \\
\hline
\end{tabular}

Source: (Garcia et al., 2018)

To know the way of elaboration of the exquisite traditional Manabí cocoa ball, qualitative, descriptive, bibliographic and analytical research was applied in such a way that the production form of the traditional cocoa ball, for which the interview was used to 10 rural women from the rural area of the Chone canton and the experimental method for the elaboration and conservation of the cocoa ball wrapped in dried guinean leaves and stored in clay pots both to the environment and in refrigeration; and packed in glass wrapped in office paper.

Creole cocoa beans characterized by their excellent quality, aroma and flavor are collected and placed in tendales or sliding to reduce their moisture content that is normally above $60 \%$ to $8 \%$ or less of humidity. Both in the tendales and in the sliding ones a natural drying with the solar energy in a range of 2 to 5 days is realized depending on the levels of luminosity. Next, the dry beans are roasted over a low heat, using a clay comal and a wood fire as a source of heat, for approximately 20 minutes, in order to separate the husk from the grain, as well as to develop the preformed aromas during fermentation, eliminate volatile acids, reduce the moisture content and the bacterial population. Remove the comal from the stove and let it cool a bit, then begin to remove the husks with your hand.

Again the separated grains are brought to a slow fire, some spices (cinnamon, sweet clove, star) are added so that the aromas are incorporated into the roasted cocoa for about 15 minutes, stirring constantly to avoid burns in the grain. Would affect the quality of the cocoa mass. The next step is the grinding of the grains by means of a crown mill, in the finest way possible, then the egg whites are added and kneading is carried out until a homogeneous paste is obtained. With the paste, the cocoa balls are formed, which really have an ovoidal shape and have an average weight of 30 gr. The cocoa balls are wrapped in office paper and stored in matianchos or clay pots covered by a lily.

\section{Results and Discussions}

Among the results obtained in the conservation of the cocoa ball, both in the environment and in controlled temperature, in a clay container with dry banana leaf wrapping and zapan mooring; and stored in glass with wrapping of office paper, you have to:

In conservation at room temperature wrapped in dried leaves of banana moored with zapan and stored in clay pots, the cocoa balls can last up to 180 days maintaining their color dark coffee, the uncharacteristic smell, the semi-bitter taste and the appearance with some whitish veins, which make it edible. However, it is at 150 days when the cocoa balls preserved in clay pots maintain their characteristic aroma, flavor, color and appearance. 
Regarding the conservation of cocoa balls wrapped in office paper and packed in glass, it was found that they have a maximum duration of 60 days, with a dark brown coloration, odor and uncharacteristic flavors, appearance with some whitish veins. The following results were obtained are shown in table 2 .

Table 2

Conservation to the environment

\begin{tabular}{|c|c|c|c|c|c|c|}
\hline \multirow{2}{*}{ Packaging } & \multicolumn{6}{|c|}{ Days } \\
\hline & 30 & 60 & 90 & 120 & 150 & 180 \\
\hline $\begin{array}{l}\text { Mud with } \\
\text { dry banana } \\
\text { leaf wrap } \\
\text { and zapán } \\
\text { tie }\end{array}$ & $\begin{array}{l}\text { Color: dark } \\
\text { coffee. } \\
\text { Smell: very } \\
\text { pleasant } \\
\text { Taste: bitter } \\
\text { Appearanc: } \\
\text { normal. }\end{array}$ & $\begin{array}{l}\text { Dark coffee } \\
\text { colour. } \\
\text { Smell: very } \\
\text { pleasant } \\
\text { Taste: } \\
\text { bitter } \\
\text { Appearanc: } \\
\text { normal. }\end{array}$ & $\begin{array}{l}\text { Dark coffee } \\
\text { colour. } \\
\text { Smell: very } \\
\text { pleasant } \\
\text { Taste: bitter } \\
\text { Appearance: } \\
\text { normal. }\end{array}$ & $\begin{array}{l}\text { Dark coffee } \\
\text { colour. } \\
\text { Smell: pleasant } \\
\text { Taste: bitter } \\
\text { Appearance: } \\
\text { some whitish } \\
\text { veins. }\end{array}$ & $\begin{array}{l}\text { Dark coffee } \\
\text { colour. } \\
\text { Smell: } \\
\text { uncharacteri } \\
\text { stic } \\
\text { Taste: semi } \\
\text { bitter } \\
\text { Appearance: } \\
\text { some } \\
\text { whitish } \\
\text { veins. }\end{array}$ & $\begin{array}{l}\text { Dark coffee } \\
\text { colour. } \\
\text { Smell: } \\
\text { uncharacteri } \\
\text { stic } \\
\text { Taste: semi } \\
\text { bitter } \\
\text { Appearance: } \\
\text { some } \\
\text { whitish } \\
\text { veins. }\end{array}$ \\
\hline $\begin{array}{l}\text { Glass with } \\
\text { office paper } \\
\text { wrapper }\end{array}$ & $\begin{array}{l}\text { Color: dark } \\
\text { coffee. } \\
\text { Smell: very } \\
\text { pleasant } \\
\text { Taste: bitter } \\
\text { Appearanc: } \\
\text { normal. }\end{array}$ & $\begin{array}{l}\text { Dark coffee } \\
\text { colour. } \\
\text { Smell: very } \\
\text { pleasant } \\
\text { Taste: } \\
\text { bitter } \\
\text { Appearanc: } \\
\text { normal. }\end{array}$ & $\begin{array}{l}\text { Dark coffee } \\
\text { colour. } \\
\text { Smell: very } \\
\text { pleasant } \\
\text { Taste: bitter } \\
\text { Appearance: } \\
\text { normal. }\end{array}$ & $\begin{array}{l}\text { Dark coffee } \\
\text { colour. } \\
\text { Smell: } \\
\text { uncharacteristic } \\
\text { Taste: } \\
\text { uncharacteristic } \\
\text { Appearance: } \\
\text { some whitish } \\
\text { veins. }\end{array}$ & $\begin{array}{l}\text { Dark coffee } \\
\text { colour. } \\
\text { Smell: } \\
\text { rancid } \\
\text { Taste: } \\
\text { rancid } \\
\text { Appearance: } \\
\text { increase in } \\
\text { whitish } \\
\text { veins. }\end{array}$ & $\begin{array}{l}\text { Color: } \\
\text { whitish. } \\
\text { Smell: } \\
\text { rancid } \\
\text { Taste: } \\
\text { rancid } \\
\text { Appearance: } \\
\text { (Lama) } \\
\text { Fungus on } \\
\text { the product. }\end{array}$ \\
\hline
\end{tabular}

Source: (García et al., 2018)

At controlled temperature (refrigeration) using earthenware pots with wraps of dried guinean leaves tied with zapan, 100 days are achieved maintaining the dark brown coloration, the characteristic odor, the flavor semi bitter and appearances with some whitish veins.

Using the glass container with the wrapping of office paper, the 90 days were achieved with a dark brownish white coloration, an uncharacteristic odor, a semi-bitter-rancid flavor and an appearance with some whitish veins. The results are shown in table 3.

Table 3

Refrigeration

\begin{tabular}{clllllll}
\hline \multirow{2}{*}{ Packages } & \multicolumn{7}{c}{ Days } \\
\cline { 2 - 8 } & \multicolumn{1}{c}{20} & 40 & \multicolumn{1}{c}{60} & \multicolumn{1}{c}{100} & \multicolumn{1}{c}{120} & 140 \\
\hline Clay mud & Color: & Dark & Dark & Dark & Dark & Dark coffee & Dark coffee \\
flakes & dark & coffee & coffee & coffee & coffee & colour. & colour. \\
with dry & coffee. & colour. & colour. & colour. & colour. & Smell: & Smell: \\
banana & Smell: & Smell: & Smell: & Smell: & Smell: & pleasant & pleasant \\
leaf & very & very & very & very & very & Taste: bitter. Taste: semi \\
wrapping & pleasant & pleasant & pleasant & pleasant & pleasant & Appearance: bitter. \\
and zapán & Taste: & Taste: & Taste: & Taste: & Taste: & some & Appearance: \\
mooring & bitter & bitter & bitter & bitter & bitter & whitish & some \\
& Appearanc & Appearanc & Appearanc & Appearanc & Appearanc & veins. & whitish \\
\hline
\end{tabular}

Zambrano, T. Y. M., Castro, I. C. G., Plaza, C. L. M., \& Farfan, R. M. (2019). Recovery of ancestral knowledge for production of traditional Manabí cocoa paste. International Journal of Life Sciences, 3(1), 71-78. https://doi.org/10.29332/ijls.v3n1.274 


\begin{tabular}{clllllll}
\hline & & & & & & & \\
\hline & e: normal. & e: normal. & e: normal. & e: normal. & e: normal. & & veins. \\
\hline Glass with & Color: & Dark & Dark & Dark & Dark & Color: & Color: \\
office & dark & coffee & coffee & coffee & coffee & whitish dark whitish dark \\
paper & coffee. & colour. & colour. & colour. & colour. & coffee. & coffee. \\
wrapper & Smell: & Smell: & Smell: & Smell: & Smell: & Smell: semi Smell: semi- \\
& very & very & very & very & pleasant & pleasant & rancid \\
& pleasant & pleasant & pleasant & pleasant & Taste: & Taste: semi Taste: bitter \\
& Taste: & Taste: & Taste: & Taste: & bitter & bitter and and rancid. \\
& bitter & bitter & bitter & bitter & Appearanc & semi-rancid. Appearance: \\
& Appearanc & Appearanc & Appearanc & Appearanc & e: normal. & Appearance: increase in \\
& e: normal. & e: normal. & e: normal. & e: normal. & & some & whitish \\
& & & & & & whitish & veins.
\end{tabular}

Source: (García et al., 2018)

According to the publication of Kuna (2017), the best way to preserve chocolate is to keep it in a cool, dry place and away from very strong odors. The most important thing is that chocolate does not suffer sudden changes in temperature. The ideal temperature is between 15 and $18^{\circ} \mathrm{C}$. If the chocolate is at a low temperature, it may lose aromas, and if it is at a high temperature, its texture and appearance may vary. In terms of humidity, it should be around $60 \%$. In the refrigerator, this humidity is greater, which affects the gloss and finish of the chocolate, appearing a layer or white spots known as fat-bloom.

The cocoa ball preserved at room temperature wrapped in dried guinean leaves tied with zapán and stored in clay pots, the cocoa balls can last up to 150 days maintaining their characteristic aroma, flavor, color, and appearance.

In this way the results obtained are consistent with the aforementioned publication, since the basic principles of conservation lie in the protection of the product from moisture, strong odors, and high temperatures; so organic preservatives such as the dried banana leaf and clay pot are essential to preserve their aroma, color, taste and appearance properties.

\section{Conclusion}

The recovery of ancestral knowledge regarding the conservation of the cocoa ball with all its characteristics, nutritional and medicinal properties is fundamental for the functional use of this food of the basic family basket.

The conservation of the traditional ball of cocoa in organic packaging such as the wrapping in dry leaf of banana and mooring of zapan placed in clay pots properly covered are a natural and friendly alternative to the environment, without the use of plastics and disposable materials that they affect the quality of the product, therefore it is a guarantee of the use of cocoa with all its benefits.

The research has a social and cultural impact in that it has recovered the ancestral wisdom of the elaboration and above all of the conservation of the cocoa balls for a longer time using wraps and organic containers like the dry leaf of banana and the covered clay pot with dry banana leaf tied with zapan.

It presents an economic impact because it presents an alternative especially for housewives to generate income by providing an added value to the cocoa bean, roasting it, grinding it and forming the traditional cocoa ball, to market it among consumers.

There is no positive environmental impact, since when extracting the fruit from the cacao creole bushes, it does not cause damage to the tree, as it is a perennial crop that is harvested up to 5 times average in the year and generally the cocoa plantations rarely they are eradicated by their producers, unless there is an uncontrollable pest.

\section{Acknowledgments}

The authors thank the students who are currently investigating how to recover of ancestral knowledge for the production of traditional Manabi cocoa paste. 
References

Campoverde, M. \& Moreno, M. (2013). Confectionery with 60\% organic chocolate. Cuenca: University of Cuenca.

Chávez, Hernández, Mercado \& Palacios. (2008). the importance of chocolate in Mexican gastronomy. Mexico: National Polytechnic Institute, School of Tourism.

Egas, M. (2015). Evaluation and technical-financial analysis of the process of pressing cocoa liquor (Theobroma cacao) to obtain cocoa butter and powder. Quito: National Polytechnic School.

Estrada, M. \& Castellano, X. (2011). Technical guide to the cultivation of cocoa managed with agroecological techniques. San Salvador, El Salvador: CATIE Tropical Agricultural Research and Higher Education Center.

Iñamagua (September 30, 2016). Cocoa, a product of ancestral medicine. Diario de Cuenca, p. 1.

Kuna Yala SL. (May 31, 2017). Chocolates.Retrieved from How to preserve chocolate ?: https://www.quierochocolate.com

Lázaro, C., Enrique, C., Jaramillo Villanueva, J. L., Córdova Ávalos, V., Carranza Cerda, I., \& Morales Jiménez, J. (2018). Chocolate casero tradicional en la región de la Chontalpa Tabasco, México: actores y saberes locales. Estudios sociales. Revista de alimentación contemporánea y desarrollo regional, 28(52), 2-27. http://www.scielo.org.mx/scielo.php?script=sci_arttext\&pid=S2395-91692018000100005

Lizcano, E. \& Fernández, J. (2014). Local knowledge and scientific knowledge. Interstices: Sociological Review of Critical Thinking, 8(2), 123-138.

Macías, T. (2018). Comparative analysis of the organic and conventional production of Theobroma cacao L. in the parish Membrillo of the Bolivar canton. Portoviejo: Technical University of Manabí.

Pedrero, E. (2011). Scientific culture and pseudoscience. Cuban Journal of Physics, 28(1), 77-80.

Perea-Villamil, JA, Cadena-Cala, T., \& Herrera-Ardila, J. (2009). The cocoa and its products as antioxidant source: Processing effect. Magazine of the Industrial University of Santander. Health , 41 (2), 128-134. http://www.scielo.org.co/scielo.php?pid=S0121-08072009000200003\&script=sci_arttext\&tlng=pt

Zambrano, T. Y. M., Castro, I. C. G., Plaza, C. L. M., \& Farfan, R. M. (2019). Recovery of ancestral knowledge for production of traditional Manabí cocoa paste. International Journal of Life Sciences, 3(1), 71-78. https://doi.org/10.29332/ijls.v3n1.274 


\section{Biography of Authors}

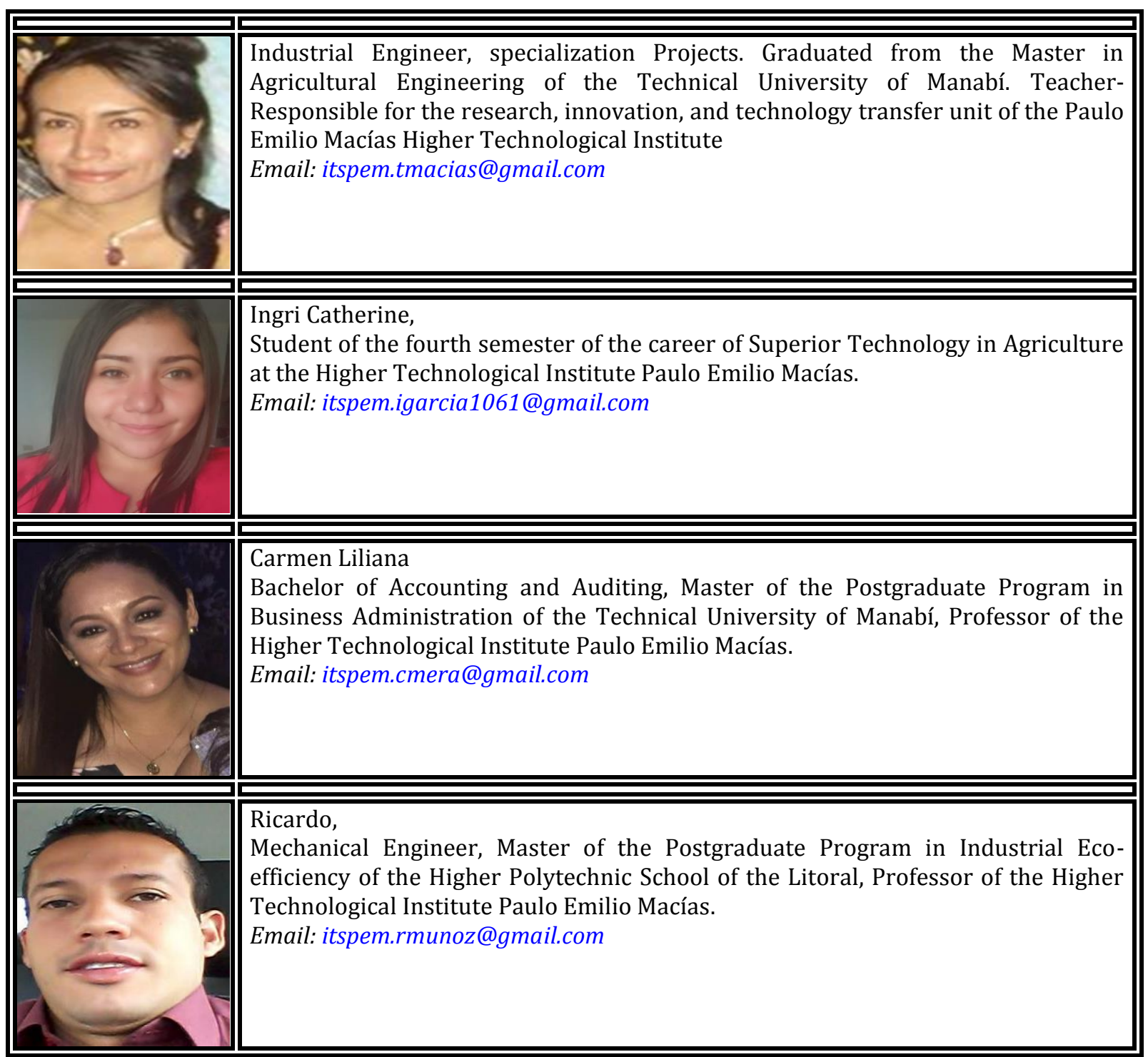

